\title{
Biological activities of marine invertebrates extracts from the northeast brazilian coast
}

\author{
C. Lhullier $a^{*}$ (D) M. I. G. Moritz ${ }^{a}$, E. O. Tabalipa ${ }^{a}$, F. N. Sardáa, \\ N. F. Z. Schneider ${ }^{b}$, M. H. Moraes ${ }^{c}$, L. Constantino ${ }^{a}$ (D), F. H. Reginatto ${ }^{a}$, M. Steindel ${ }^{c}$ (D), \\ U. S. Pinheiro ${ }^{d}$, C. M. O. Simões ${ }^{b}$, C. D. Pérez ${ }^{e}$ (D), E. P. Schenkel ${ }^{a}$
}

${ }^{a}$ Laboratório de Produtos Naturais, Departamento de Ciências Farmacêuticas, Universidade Federal de Santa Catarina UFSC, Rua Eng. Agronômico Andrei Cristian Ferreira, s/n, Campus Trindade, CEP 88040-900, Florianópolis, SC, Brasil

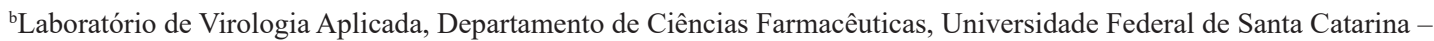
UFSC, Rua Eng. Agronômico Andrei Cristian Ferreira, s/n, Campus Trindade, CEP 88040-900, Florianópolis, SC, Brasil

${ }^{c}$ Laboratório de Protozoologia, Departamento de Microbiologia, Imunologia e Parasitologia, Universidade Federal de Santa Catarina - UFSC, Rua Eng. Agronômico Andrei Cristian Ferreira, s/n, Campus Trindade, CEP 88040-900, Florianópolis, SC, Brasil

${ }^{\text {d} D e p a r t a m e n t o ~ d e ~ Z o o l o g i a, ~ C e n t r o ~ d e ~ C i e ̂ n c i a s ~ B i o l o ́ g i c a s, ~ U n i v e r s i d a d e ~ F e d e r a l ~ d e ~ P e r n a m b u c o ~-~ U F P E, ~ A v . ~ P r o f . ~}$ Moraes Rego, 1235, Cidade Universitária, CEP 50670-901, Recife, PE, Brasil

${ }^{\text {e}}$ Centro Acadêmico de Vitória, Universidade Federal de Pernambuco - UFPE, Rua Alto do Reservatório, s/n, Bela Vista, CEP 55608-680, Vitória de Santo Antão, PE, Brasil

*e-mail: 1hulliercintia@gmail.com

Received: September 6, 2018 - Accepted: November 23, 2018 - Distributed: May 31, 2020

\begin{abstract}
This paper reports the in vitro antiproliferative effects, antiprotozoal, anti-herpes and antimicrobial activities of 32 organic extracts of 14 marine sponges and 14 corals collected in northeast Brazilian coast. The ethanolic extracts of the sponges Amphimedon compressa and Tedania ignis, and the acetone extract of Dysidea sp. showed relevant results concerning the antiproliferative effects against A549, HCT-8, and PC-3 cell lines by sulforhodamine B assay, but also low specificity. Concerning the antiprotozoal screening, the ethanolic extract of Amphimedon compressa and the acetone and ethanolic extracts of Dysidea sp. were the most active against Leishmania amazonensis and Trypanosoma cruzi expressing $\beta$-galactosidase in THP-1 cells. In the preliminary anti-HSV-1 (KOS strain) screening, the ethanolic extracts of the sponges Amphimedon compressa, Haliclona sp. and Chondrosia collectrix inhibited viral replication by more than $50 \%$. The most promising anti-herpes results were observed for the ethanolic extract of Haliclona sp. showing high selective indices against HSV-1, KOS and 29R strains (SI>50 and $>79$, respectively), and HSV-2, 333 strain (IS>108). The results of the antibacterial screening indicated that only the ethanolic extract of Amphimedon compressa exhibited a weak activity against Enterococcus faecalis, Pseudomonas aeruginosa and Escherichia coli by the disk diffusion method. In view of these results, the extracts of Amphimedon compressa, Tedania ignis and Dysidea sp. were selected for further studies aiming the isolation and identification of the bioactive compounds with antiproliferative and/or antiprotozoal activities. The relevant anti-herpes activity of the ethanolic extract of Haliclona sp. also deserves special attention, and will be further investigated.
\end{abstract}

Keywords: marine invertebrates, antiproliferative effects, anti-herpes activity, antiprotozoal activity, antimicrobial activity.

\section{Atividades biológicas de extratos de invertebrados marinhos da costa nordeste do Brasil}

\section{Resumo}

Este artigo reporta as atividades in vitro antiproliferativa, atiprotozoárica, anti-herpética e antimicrobiana de 32 extratos orgânicos provenientes de 14 esponjas marinhas e 14 corais coletados no litoral nordestino brasileiro. Os extratos etanólicos das esponjas Amphimedon compressa e Tedania ignis, e o extrato acetônico de Dysidea sp. demonstraram resultados promissores em relação aos efeitos antiproliferativos frente as linhagens celulares A549, HCT-8, PC-3 pelo método da sulforrodamina $\mathrm{B}$, mas sem especificidade. Em relação à atividade antiprotozárica, os extratos etanólico de Amphimedon compressa e acetônico e etanólico de Dysidea sp. apresentaram atividade contra Leishmania amazonensis e Trypanosoma cruzi através do método de expressão de $\beta$-galactosidase em células THP-1. Na investigação preliminar de atividade antiviral frente ao vírus Herpes simplex tipo 1 (cepa KOS), os extratos etanólicos das esponjas Amphimedon compressa, Haliclona sp. e Chondrosia collectrix inibiram mais de 50\% da replicação viral. O extrato etanólico da esponja 
Haliclona sp. demonstrou resultados promissores para atividade anti-herpética com altos índices de seletividade para as cepas KOS (IS > 50) e 29R (IS>79) frente ao VHS-1 e cepa 333 (IS>108) frente ao VHS-2. O extrato etanólico da esponja Amphimedon compressa exibiu uma pequena atividade contra Enterococcus faecalis, Pseudomonas aeruginosa and Escherichia coli pelo método de difusão em disco. De acordo com os resultados apresentados, os extratos das esponjas Amphimedon compressa, Tedania ignis e Dysidea sp. serão selecionados para futuros estudos de isolamento e identificação dos compostos bioativos para as atividades antiproliferativa e antiprozoárica. O extrato etanólico de Haliclona sp. será investigado por possuir atividade relevante anti-herpética.

Palavras-chave: invertebrados marinhos, atividade antiproliferativa, atividade anti-herpética, atividade antiprotozoárica, atividade antimicrobiana.

\section{Introduction}

Most of the natural products used in therapeutics come from terrestrial organisms. However the marine environment allowed a new approach for the discovery of chemical molecules and biological activities. The marine habitat is a prolific source of bioactive secondary metabolites with potential to treat several diseases (Montaser and Luesch, 2011). A comparative analysis performed by Kong and coworkers showed that marine natural products are superior to terrestrial natural products in terms of chemical novelty and significant bioactivity. The analysis, which compared molecular scaffolds reported in the Dictionary of Natural Products (DNM) to those in the Dictionary of Marine Natural Products (DMNP), showed that approximately $71 \%$ of the molecular scaffolds in the DMNP were exclusively found in marine organisms (Kong et al., 2010).

Despite the large number of natural products isolated from marine sources in the last decade that show high bioactivity for a variety of diseases, only few have the chance to get to the end of drug discovery pipeline (Blunt et al., 2010, 2017). Nevertheless, worldwide bioprospecting efforts have not ceased, and marine invertebrates are amongst the top group of organisms that have contributed for this fact with a larger number of new molecules entries in Natural Products libraries (Jha and Xu, 2004; Blunt et al., 2008). Leal and coworkers showed that between 2000 and 2009, a great number of natural products from marine invertebrates was isolated from the phyla Porifera (47\%) and Cnidaria (33\%) (Leal et al., 2012).

Sponges (phylum Porifera) are primitive filter-feeders, about 9,000 species already described, but it is thought that there are more than 20,000 marine sponges. They can produce high levels of cytotoxic compounds, the majority coming from the secondary metabolism protecting them against predation, overgrowth by fouling organisms, and/or competition for space (Perdicaris et al., 2013). It was proved that marine sponges produce an enormous array of antitumor, antiviral, anti-inflammatory, immunosuppressive, antibiotic, and other bioactive molecules that have potential for therapeutic use. Many bioactive metabolites from sponges proved to be inhibitors of certain enzymes, which often mediate or produce mediators of intracellular or intercellular messengers involved in diseases pathogenesis (Sagar et al., 2010; Villa and Gerwick, 2010; Frota et al., 2012).

The phylum Cnidaria is a large, diverse and ecologically important group of marine invertebrates that includes over
11,000 existing species (Daly et al., 2007). Over 3,000 marine natural products have been described and the researches have been demonstrated that compounds produced by cnidarians are more than just toxins and venoms (Rocha et al., 2011). The class Anthozoa currently includes over 7,500 valid species (about $2 / 3$ of all known cnidarian species) (Daly et al., 2007). Within the Anthozoa, the soft corals or octocorals are the ones, which have contributed with the highest number of promising bioactive marine compounds, although other groups, such as Actiniaria (sea anemones) and Scleractinia (hard corals), have also yielded relevant compounds (Štrukelj et al., 2000; Fontana et al., 1998; Miyaoka et al., 2006; Meyer et al., 2009).

Despite the great biodiversity present along the Brazilian coastline, an important source of potential biologically active compounds, chemical analysis and bioprospection screening of Brazilian marine organisms is still incipient (Almeida et al., 2014). To this point, the chemistry of marine natural products in Brazil has been focused on sponges, tunicates and brown algae (Berlinck et al., 2004). Concerning the chemical studies on octocorals, from the approximately 107 species reported in Brazil to the present date only twenty have been studied, thirteen of them by Brazilian research groups (Almeida et al., 2014).

So far, most of the bioprospection studies on marine organisms extracts conducted in Brazil were focused on evaluating their cytotoxic and antimicrobial activities (Seleghim et al., 2007; Monks et al., 2002; Rangel et al., 2001). In addition, the collection range of these organisms on the Brazilian coast is concentrated in the south and southeast regions of the country (Seleghim et al., 2007; Monks et al., 2002; Rangel et al., 2001). Based on these data and the urgent requirement to discover new molecules for the treatment of neglected tropical diseases, such as Chagas disease and leishmaniasis, we evaluated the in vitro antiproliferative, antiprotozoal, anti-herpes, and antimicrobial activities of 32 organic extracts obtained from 14 marine sponges and 14 coral species from the northeastern Brazilian coast.

\section{Materials and Methods}

\subsection{Collection of the marine organisms}

The marine sponges and corals were collected in June 2016 at Ponta de Pedra beach, Goiana, Pernambuco State (07'33'38' S; 35 $\left.00^{\circ} 09^{\prime \prime} \mathrm{W}\right)$ and Ponta de Mangue beach, Maragogi, Alagoas State $\left(09^{\circ} 02^{\prime} 46^{\prime \prime} \mathrm{S} ; 3^{\circ} 12^{\prime} 12^{\prime \prime} \mathrm{W}\right)$, 
Brazil (Table 1). They were frozen and taken to the Laboratory of Natural Products in Santa Catarina State. The sponges and corals were identified by two of the authors (U.S.P. and C.D.P, respectively), and are kept in the Porifera Collection of the Universidade Federal de Pernambuco (UFPEPOR) and in the Cnidaria Collection of the Centro Acadêmico de Vitoria of the Universidade Federal de Pernambuco (GPA). The organisms used for the analyzes are all colonial and we collected a portion of them. They have a high vegetative growth and they can regenerate the lost portion, for this reason the populations of these organisms are not affected by the sampling.

\subsection{Preparation of the extracts}

The extracts of marine sponges were obtained using different organic solvents. Initially, an acetone (A) extraction was performed for seven days. After, the same samples were extracted with ethanol (E) followed by dichloromethane (D). All the extracts were firstly evaporated to dryness in a rotary evaporator, kept in the freezer and submitted to an evaluation by ${ }^{1} \mathrm{H}$ NMR to look for chemical similarities. Pharmacological screenings were performed with all ethanolic extracts, whereas only some acetone and dichlorometane extracts, which showed different ${ }^{1} \mathrm{H}$ NMR profiles to those of ethanolic extracts, were pharmacologically evaluated. The corals analyzed in this work were only extracted with ethanol for seven days.

\subsection{Antibacterial assays}

The microorganism strains tested came from the American Type Culture Collection (ATCC): Enterococcus faecalis (ATCC 29212). Pseudomonas aeruginosa (ATCC 27853) and Escherichia coli (ATCC 25922). The antibacterial activity was evaluated by the disk diffusion method as previously described by de Oliveira et al. (2005) with minor modifications. Briefly, filter paper disks $(6 \mathrm{~mm})$ were impregnated with $20 \mu \mathrm{l}$ of the extracts $(100 \mathrm{mg} / \mathrm{mL})$ and then placed on Mueller-Hinton agar plates (HIMEDIA ${ }^{\circledR}$ ), which were inoculated with these microorganisms according to the standard protocol described by the Clinical Laboratory Standard Institute (CLSI, 2012). The plates were incubated at $35^{\circ} \mathrm{C}\left( \pm 1{ }^{\circ} \mathrm{C}\right)$ and after $18 \mathrm{~h}$ the diameters of the inhibition zones were measured. Filter-paper disks containing DMSO were used as negative control and no

Table 1. Marine organisms collected from Northeastern Brazilian coast.

\begin{tabular}{|c|c|c|}
\hline Species & \multirow{2}{*}{ Family } & \multirow{2}{*}{ Collection site } \\
\hline Sponges & & \\
\hline Amphimedon compressa & Niphatidae & Ponta de Pedra beach $\left(07^{\circ} 33^{\prime} 38^{\prime \prime} \mathrm{S} ; 35^{\circ} 00^{\prime} 09^{\prime \prime} \mathrm{W}\right)$ \\
\hline Chondrilla caribensis & Chondrillidae & Ponta de Mangue beach $\left(09^{\circ} 02^{\prime} 46^{\prime \prime} \mathrm{S} ; 35^{\circ} 12^{\prime} 12^{\prime \prime} \mathrm{W}\right)$ \\
\hline Chondrosia collectrix & Chondrosiidae & Ponta de Mangue beach $\left(09^{\circ} 02^{\prime} 46^{\prime \prime} \mathrm{S} ; 35^{\circ} 12^{\prime} 12^{\prime \prime} \mathrm{W}\right)$ \\
\hline Cinachyrella sp. & Tetillidae & Ponta de Mangue beach $\left(09^{\circ} 02^{\prime} 46^{\prime \prime} \mathrm{S} ; 35^{\circ} 12^{\prime} 12^{\prime \prime} \mathrm{W}\right)$ \\
\hline Cladocroce caelum & Chalinidae & Ponta de Mangue beach $\left(09^{\circ} 02^{\prime} 46^{\prime \prime} \mathrm{S} ; 35^{\circ} 12^{\prime} 12^{\prime \prime} \mathrm{W}\right)$ \\
\hline Desmapsamma anchorata & Desmacididae & Ponta de Mangue beach $\left(09^{\circ} 02^{\prime} 46^{\prime \prime} \mathrm{S} ; 35^{\circ} 12^{\prime} 12^{\prime \prime} \mathrm{W}\right)$ \\
\hline Dysidea etheria & Dysideidae & Ponta de Mangue beach $\left(09^{\circ} 02^{\prime} 46^{\prime \prime} \mathrm{S} ; 35^{\circ} 12^{\prime} 12^{\prime \prime} \mathrm{W}\right)$ \\
\hline Dysidea sp. & Dysideidae & Ponta de Mangue beach $\left(09^{\circ} 02^{\prime} 46^{\prime \prime} \mathrm{S} ; 35^{\circ} 12^{\prime} 12^{\prime \prime} \mathrm{W}\right)$ \\
\hline Echinodictyum dendroides & Raspailiidae & Ponta de Mangue beach $\left(09^{\circ} 02^{\prime} 46^{\prime \prime} \mathrm{S} ; 35^{\circ} 12^{\prime} 12^{\prime \prime} \mathrm{W}\right)$ \\
\hline Haliclona implexiformis & Chalinidae & Ponta de Mangue beach $\left(09^{\circ} 02^{\prime} 46^{\prime \prime} \mathrm{S} ; 35^{\circ} 12^{\prime} 12^{\prime \prime} \mathrm{W}\right)$ \\
\hline Haliclona melana & Chalinidae & Ponta de Mangue beach $\left(09^{\circ} 02^{\prime} 46^{\prime \prime} \mathrm{S} ; 35^{\circ} 12^{\prime} 12^{\prime \prime} \mathrm{W}\right)$ \\
\hline Haliclona sp. & Chalinidae & Ponta de Mangue beach $\left(09^{\circ} 02^{\prime} 46^{\prime \prime} \mathrm{S} ; 35^{\circ} 12^{\prime} 12^{\prime \prime} \mathrm{W}\right)$ \\
\hline Scopalina ruetzleri & Scopalinidae & Ponta de Mangue beach $\left(09^{\circ} 02^{\prime} 46^{\prime \prime} \mathrm{S} ; 35^{\circ} 12^{\prime} 12^{\prime \prime} \mathrm{W}\right)$ \\
\hline Tedania ignis & Tedaniidae & Ponta de Pedra beach $\left(07^{\circ} 33^{\prime} 38^{\prime \prime} \mathrm{S} ; 35^{\circ} 00^{\prime} 09^{\prime \prime} \mathrm{W}\right)$ \\
\hline \multicolumn{3}{|l|}{ Corals } \\
\hline Agaricia humilis & Agariciidae & Ponta de Mangue beach $\left(09^{\circ} 02^{\prime} 46^{\prime \prime} \mathrm{S} ; 35^{\circ} 12^{\prime} 12^{\prime \prime} \mathrm{W}\right)$ \\
\hline Carijoa riisei & Clavulariidae & Ponta de Mangue beach $\left(09^{\circ} 02^{\prime} 46^{\prime \prime} \mathrm{S} ; 35^{\circ} 12^{\prime} 12^{\prime \prime} \mathrm{W}\right)$ \\
\hline Favia gravida & Faviidae & Ponta de Mangue beach $\left(09^{\circ} 02^{\prime} 46^{\prime \prime} \mathrm{S} ; 35^{\circ} 12^{\prime} 12^{\prime \prime} \mathrm{W}\right)$ \\
\hline Millepora alcicornis & Milleporidae & Ponta de Mangue beach $\left(09^{\circ} 02^{\prime} 46^{\prime \prime} \mathrm{S} ; 35^{\circ} 12^{\prime} 12^{\prime \prime} \mathrm{W}\right)$ \\
\hline Millepora brasiliensis & Milleporidae & Ponta de Mangue beach $\left(09^{\circ} 02^{\prime} 46^{\prime \prime} \mathrm{S} ; 35^{\circ} 12^{\prime} 12^{\prime \prime} \mathrm{W}\right)$ \\
\hline Montastrea cavernosa & Faviidae & Ponta de Mangue beach $\left(09^{\circ} 02^{\prime} 46^{\prime \prime} \mathrm{S} ; 35^{\circ} 12^{\prime} 12^{\prime \prime} \mathrm{W}\right)$ \\
\hline Muriceopsis sulphurea & Plexauridae & Ponta de Mangue beach $\left(09^{\circ} 02^{\prime} 46^{\prime \prime} \mathrm{S} ; 35^{\circ} 12^{\prime} 12^{\prime \prime} \mathrm{W}\right)$ \\
\hline Mussismilia harttii & Mussidae & Ponta de Mangue beach $\left(09^{\circ} 02^{\prime} 46^{\prime \prime} \mathrm{S} ; 35^{\circ} 12^{\prime} 12^{\prime \prime} \mathrm{W}\right)$ \\
\hline Mussismilia hispida & Mussidae & Ponta de Mangue beach $\left(09^{\circ} 02^{\prime} 46^{\prime \prime} \mathrm{S} ; 35^{\circ} 12^{\prime} 12^{\prime \prime} \mathrm{W}\right)$ \\
\hline Palythoa caribaeorum & Zoanthidae & Ponta de Mangue beach $\left(09^{\circ} 02^{\prime} 46^{\prime \prime} \mathrm{S} ; 35^{\circ} 12^{\prime} 12^{\prime \prime} \mathrm{W}\right)$ \\
\hline Plexaurella grandiflora & Plexauridae & Ponta de Mangue beach $\left(09^{\circ} 02^{\prime} 46^{\prime \prime} \mathrm{S} ; 35^{\circ} 12^{\prime} 12^{\prime \prime} \mathrm{W}\right)$ \\
\hline Porites asteroides & Poritidae & Ponta de Mangue beach $\left(09^{\circ} 02^{\prime} 46^{\prime \prime} \mathrm{S} ; 35^{\circ} 12^{\prime} 12^{\prime \prime} \mathrm{W}\right)$ \\
\hline Scolymia wellsi & Mussidae & Ponta de Mangue beach $\left(09^{\circ} 02^{\prime} 46^{\prime \prime} \mathrm{S} ; 35^{\circ} 12^{\prime} 12^{\prime \prime} \mathrm{W}\right)$ \\
\hline Siderastrea stellata & Siderastreidae & Ponta de Mangue beach $\left(09^{\circ} 02^{\prime} 46^{\prime \prime} \mathrm{S} ; 35^{\circ} 12^{\prime} 12^{\prime \prime} \mathrm{W}\right)$ \\
\hline
\end{tabular}


inhibition was observed. Standard antibiotic disks were selected according to the sensitivity of the microorganism tested: Ampicillin $(10 \mu \mathrm{g})$, Oxacillin $(1 \mu \mathrm{g})$, Ceftazidime $(30 \mu \mathrm{g})$ and Fluconazole $(25 \mu \mathrm{g})$.

\subsection{Antiprotozoal assays}

The trypanocidal and leishmanicidal assays were performed as previously described by Lima et al. (2016). Human monocytic leukemia cell line THP-1 (ATCC TIB202) was grown in RPMI-1640 medium without phenol red (Sigma-Aldrich, St. Louis, MO, USA) supplemented with $10 \%$ fetal bovine serum (FBS, Life Technologies, USA), $12.5 \mathrm{mM}$ HEPES, Glutamax (2 $\mathrm{mM})$, and the antibiotics penicillin $(100 \mathrm{U} / \mathrm{ml})$ streptomycin $(100 \mu \mathrm{g} / \mathrm{ml})$, at $37^{\circ} \mathrm{C}$ in a humidified $5 \% \mathrm{CO}_{2}$ atmosphere. L. amazonensis $\mathrm{MHOM} / \mathrm{BR} / 77 / \mathrm{LTB} 0016$ promastigotes expressing $\beta$-galactosidase were grown at $26{ }^{\circ} \mathrm{C}$ in Schneider's insect medium (Sigma Chemical, St. Louis, MO, USA) supplemented with $5 \%$ heat inactivated FBS and $2 \%$ human urine. For the antiprotozoal screening against intracellular L. amazonensis amastigotes, THP-1 cells $\left(4.0 \times 10^{4}\right.$ per well) were cultivated in 96 well plates in RPMI-1640 medium supplemented as described previously, and treated with $100 \mathrm{ng} / \mathrm{ml}$ of phorbol 12-myristate 13-acetate (PMA, Sigma-Aldrich) for $72 \mathrm{~h}$ at $37^{\circ} \mathrm{C}$ in a $5 \% \mathrm{CO}_{2}$ to allow THP-1 cells differentiation into non-dividing macrophages (Schwende et al., 1996). Four days old culture promastigotes $\left(4.0 \times 10^{6}\right.$ parasites $\left./ \mathrm{ml}\right)$ were washed with phosphate buffered saline (PBS), $\mathrm{pH} 7.4$, and incubated in RPMI-1640 medium supplemented with $10 \%$ heat-inactivated human $\mathrm{B}+$ serum for $1 \mathrm{~h}$ at $34^{\circ} \mathrm{C}$ to parasite opsonization. THP-1 cells were incubated with a parasite/cell ratio of $10: 1$ for $3 \mathrm{~h}$ at $34{ }^{\circ} \mathrm{C}$ and $5 \% \mathrm{CO}_{2}$. Thereafter, non-internalized parasites were removed by one wash with $\mathrm{PBS}$, and infected cells were incubated at $34{ }^{\circ} \mathrm{C}$ and $5 \% \mathrm{CO}_{2}$ with $180 \mu$ l of complete supplemented RPMI-1640 medium for another $24 \mathrm{~h}$ to allow the transformation of promastigotes into intracellular amastigotes. The $\beta$-galactosidase $T$. cruzi Tulahuen strain (Buckner et al., 1996) was kindly provided by the Laboratory of Cellular and Molecular Parasitology (Centro de Pesquisas René Rachou, FIOCRUZ, Belo Horizonte, MG, Brazil). Culture-derived trypomastigotes raised from infected L929 cell line were used to infect differentiated THP-1 cells (4.0x10 cells/well) in 96-well microplates in a parasite:cell ratio of $3: 1$ and incubated overnight at $37^{\circ} \mathrm{C}$ and $5 \% \mathrm{CO}_{2}$. The medium containing non-internalized parasites was removed by PBS washing and replaced with $180 \mu 1$ of fresh complete medium.

Extracts were solubilized in $1 \%$ dimethyl sulfoxide (DMSO) and serially diluted ( $50 \mu \mathrm{g} / \mathrm{ml}$ to $1.56 \mu \mathrm{g} / \mathrm{ml})$. Infected cell layer was treated by addition of $20 \mu \mathrm{l}$ of each sample in triplicate followed by incubation for $48 \mathrm{~h}$ at $34^{\circ} \mathrm{C}$ and $5 \% \mathrm{CO}_{2}$. After treatment, cells were carefully washed with PBS and incubated for $16 \mathrm{~h}$ at $37{ }^{\circ} \mathrm{C}$ with $250 \mu \mathrm{l}$ of chlorophenol red- $\beta$-D-galactopyranoside (Sigma-Aldrich) at $100 \mu \mathrm{M}$ and $0.1 \%$ Nonidet P-40 (Amresco, Solon, Ohio, USA). Optical densities were read at $570 / 630 \mathrm{~nm}$ in an Infinite M200 TECAN, Austria. The concentration of each sample that reduced parasite viability by $50 \%\left(\mathrm{IC}_{50}\right)$, when compared to untreated controls, was estimated by non-linear regression of concentration-response curves. Amphotericin B (Bristol-Myers. Squibb, Princeton, NJ, USA) and benznidazole (Sigma-Aldrich) were used as positive controls for leishmanicidal and trypanocidal assays, respectively, and $1 \%$ DMSO as negative control. To evaluate cell toxicity, THP- 1 cells were seeded $\left(4.0 \times 10^{4}\right.$ per well $)$ in 96-well microplates and samples at concentration ranging from $500 \mu \mathrm{g} / \mathrm{ml}$ to $15.6 \mu \mathrm{g} / \mathrm{ml}$ or $1 \%$ DMSO (negative control) were added, and cells were incubated at $37^{\circ} \mathrm{C}$ and $5 \% \mathrm{CO}_{2}$ for $72 \mathrm{~h}$. Cell viability was evaluated by the colorimetric 3-(4,5-dimethylthiazol-2-yl)-2,5-diphenyltetrazolium bromide (MTT) method and the optical densities were read at $540 \mathrm{~nm}$ in a TECAN Infinite M200 microplate reader immediately after the dissolution of formazan crystals with DMSO. The $\mathrm{CC}_{50}$ was defined as the concentration of each sample that reduced the absorbance of treated cells by $50 \%$ when compared with cell control.

\subsection{Anti-herpes assays}

VERO cells (from African Green monkey kidneys) were obtained from the American Type Culture Collection (ATCC: CCL81), and were grown in Eagle's minimum essential medium (MEM; Cultilab, Campinas. Brazil), supplemented with 10\% FBS (Gibco, Carlsbad, CA, USA), and maintained at $37{ }^{\circ} \mathrm{C}$ and $5 \% \mathrm{CO}_{2}$ in a humidified atmosphere. HSV-1 (KOS and 29R strains, which are sensitive- and acyclovir-resistant strains, respectively, Faculty of Pharmacy, University of Rennes I, Rennes, France) and HSV-2 (333 strain, Department of Clinical Virology, Göteborg University, Göteborg, Sweden) were propagated in the permissive VERO cells. Viral stocks were titrated as based on plaque forming units (PFU), counted by plaque assay as previously described (Burleson et al., 1992) and stored at $-80{ }^{\circ} \mathrm{C}$. To perform the anti-herpes screening, the viral plaque number reduction assay was used. Firstly, the cytotoxicity of the extracts was determined by sulforhodamine B (SRB) assay (Vichai and Kirtikara, 2006). In brief, VERO cells $\left(2.5 \times 10^{4}\right.$ cells per well) were exposed to different concentrations of the samples for $48 \mathrm{~h}$. After incubation, 10\% trichloroacetic acid (TCA) was added to each well to fix the cells and then washed and stained with SRB. The protein-bound dye was dissolved in $10 \mathrm{mM}$ Tris-Base [(tris(hydroxymethyl) aminomethane] solution and optical densities (OD) were read at $510 \mathrm{~nm}$ on a spectrophotometer Spectra Max M2 (Molecular Devices, USA). The 50\% cytotoxic concentration $\left(\mathrm{CC}_{50}\right)$ was defined as the concentration that reduced cell viability by $50 \%$ when compared to untreated controls. Thereafter, the potential antiherpes activity was screened by plaque number reduction assay as described previously by Boff et al. (2016). Briefly, confluent cell monolayers $\left(2.5 \times 10^{5}\right.$ cells per well $)$ were infected with approximately $100 \mathrm{PFU}$ of each virus strain for $1 \mathrm{~h}$ at $37^{\circ} \mathrm{C}$. Treatments were performed by adding non-cytotoxic concentrations of the extracts for VERO cells after viral infection (post infection treatment). Cells were then washed with 
phosphate-buffered saline (PBS) and overlaid with MEM containing 1.5\% carboxymethylcellulose (CMC; Sigma-Aldrich) in the presence or absence of different concentrations of the compounds, and incubated for $48 \mathrm{~h}$. Cells were fixed and stained with naphthol blue-black (Sigma-Aldrich) and viral plaques were counted by using a stereomicroscope. The results are presented as percentages of viral inhibition or by $\mathrm{IC}_{50}$ values, which were defined as the concentration of each sample that inhibited viral plaque formation by $50 \%\left(\mathrm{IC}_{50}\right)$, when compared to untreated controls. The ratio between $\mathrm{CC}_{50}$ and $\mathrm{IC}_{50}$ values was calculated to obtain the selectivity index (SI) of each sample. Acyclovir (ACV, Sigma-Aldrich) was used as positive control to HSV-1 (KOS strain) and HSV-2 (333 strain) and as negative control to HSV-1 (29-R strain) replication.

\subsection{Antiproliferative assays}

Non-small cells of human lung cancer cells (A549, ATCC: CCL 195) were grown in Eagle's minimum essential medium (MEM; Cultilab, Campinas. Brazil); human ileocecal adenocarcinoma cells (HCT-8, Adolfo Lutz Institute, São Paulo, SP, Brazil) were grown in RPMI-1640 medium, Cultilab); and no hormone-sensitive human prostate adenocarcinoma cells (PC-3, German Collection of Microorganisms and Cell Cultures, DSMZ. Braunschweig, Germany) were cultivated in Dulbecco's Modified Eagle's Medium (DMEM, Cultilab) supplemented with 1\% glutamine. All cells were supplemented with $10 \% \mathrm{FBS}$, and maintained at $37^{\circ} \mathrm{C}$ and $5 \% \mathrm{CO}_{2}$. The antiproliferative screening was performed by sulforhodamine B assay (SRB) (Vichai and Kirtikara, 2006) as described above (item 2.5). A549, HCT-8 and PC3 cells were seeded in 96-well plates $\left(2.5 \times 10^{4}\right.$ cells per well $)$ and exposed to different concentrations of the extracts for $48 \mathrm{~h}$. Paclitaxel was used as positive control. After the incubation period, the $50 \%$ inhibitory concentration $\left(\mathrm{IC}_{50}\right)$ of each compound was defined as the concentration that inhibited cell viability by $50 \%$ when compared to untreated controls.

\subsection{Statistical analysis}

The mean values \pm standard deviations (SD) are representative of two or three independent experiments. For the determination of $\mathrm{IC}_{50}$ values, nonlinear regressions of concentration-response curves were used.

\section{Results}

The results concerning the antiproliferative, antiprotozoal, anti-herpes and antimicrobial screenings of the organic extracts are described below, and four sponge species demonstrated antiproliferative, antiprotozoal, anti-herpes and/or antibacterial activities.

\subsection{Antiproliferative effects}

Thirty-two organic extracts of 28 species of marine invertebrates (14 sponges and 14 coral species) were screened for antiproliferative effects of the human cancer A549, HCT-8 and PC-3 cell lines. From them, the sponges Amphimedon compressa (ethanolic extract), Dysidea sp. (acetone extract), and Tedania ignis (ethanolic extract) showed the lowest $\mathrm{IC}_{50}$ values against the tested cancer cell lines as well as against VERO cells. Despite of the fact that VERO cells are fibroblasts derived from kidneys of healthy monkeys and, consequently, a comparison with cancer cell lines is not adequate, the obtained results seem to indicate that these sponge extracts are active but present low specificity (Table 2).

Table 2. Antiproliferative effects of marine invertebrate extracts (sponges and corals) on non-small cells of human lung cancer (A549), human colon carcinoma (HCT-8), human prostate cancer (PC-3), and Vero (healthy fibroblasts from kidneys of African Green monkey) cell lines, after $48 \mathrm{~h}$ of treatment by the sulforhodamine B assay. Data are presented as $\mathrm{IC}_{50}$ values $(\mu \mathrm{g} / \mathrm{mL})$ and $95 \%$ confidence intervals obtained by non-linear regression.

\begin{tabular}{|c|c|c|c|c|c|}
\hline \multirow{2}{*}{ Species } & \multirow{2}{*}{ Extracts } & \multicolumn{4}{|c|}{ Cell lines } \\
\hline & & A549 & HCT-8 & PC-3 & VERO \\
\hline Sponges & & $\mathrm{IC}_{\mathrm{s}}$ & (95\% confidenc & interval) & \\
\hline Amphimedon compressa & $\mathrm{E}$ & $\begin{array}{c}8.06 \\
(6.1-11.5)\end{array}$ & $\begin{array}{c}7.12 \\
(5.2-13.6)\end{array}$ & $\begin{array}{c}8.06 \\
(6.1-11.5)\end{array}$ & $\begin{array}{c}9.9 \\
(7.2-13.6)\end{array}$ \\
\hline Chondrilla caribensis & A & $>500$ & $>500$ & $>500$ & $>500$ \\
\hline Chondrilla caribensis & $\mathrm{E}$ & $>500$ & $>500$ & $>500$ & $>500$ \\
\hline Chondrosia collectrix & $\mathrm{E}$ & $\begin{array}{c}420.4 \\
(305.5-578.6)\end{array}$ & $\begin{array}{c}405.7 \\
(336.4-489.1)\end{array}$ & $\begin{array}{c}420.3 \\
(265.2-566.2)\end{array}$ & $\begin{array}{c}412.6 \\
(352.8-482.6)\end{array}$ \\
\hline Chondrosia collectrix & $\mathrm{D}$ & $\begin{array}{c}476.5 \\
(361.6-627.8)\end{array}$ & $>500$ & $>500$ & $>500$ \\
\hline Cinachyrella sp. & $\mathrm{E}$ & $>500$ & $\begin{array}{c}383.2 \\
(269.2-545.4)\end{array}$ & $\begin{array}{c}394.8 \\
(183.4-549.8)\end{array}$ & $\begin{array}{c}340.6 \\
(291.6-397.9)\end{array}$ \\
\hline Cladocroce caelum & $\mathrm{E}$ & $\begin{array}{c}316.2 \\
(133.99-400)\end{array}$ & $\begin{array}{c}211.8 \\
(184.5-243.2)\end{array}$ & $\begin{array}{c}262.2 \\
(236.9-290.3)\end{array}$ & $\begin{array}{c}391.3 \\
(347.4-440.6)\end{array}$ \\
\hline Desmapsamma anchorata & $\mathrm{E}$ & $>500$ & $>500$ & $>500$ & $>500$ \\
\hline Dysidea etheria & $\mathrm{E}$ & $\begin{array}{c}273 \\
(218.9-340.5)\end{array}$ & $\begin{array}{c}186.3 \\
(164.7-210.8)\end{array}$ & $\begin{array}{c}271.8 \\
(209.0-353.5)\end{array}$ & $\begin{array}{c}221.6 \\
(200.7-244.8)\end{array}$ \\
\hline
\end{tabular}

A: acetone extract; E: ethanolic extract; D: dichloromethane extract. 
Table 2. Continued...

\begin{tabular}{|c|c|c|c|c|c|}
\hline \multirow{2}{*}{ Species } & \multirow{2}{*}{ Extracts } & \multicolumn{4}{|c|}{ Cell lines } \\
\hline & & A549 & HCT-8 & PC-3 & VERO \\
\hline Sponges & \multicolumn{5}{|c|}{$\mathrm{IC}_{50}(95 \%$ confidence interval $)$} \\
\hline Dysidea etheria & A & $>500$ & $>500$ & $\begin{array}{c}481.9 \\
(400.5-579.9)\end{array}$ & $>500$ \\
\hline Dysidea $\mathrm{sp}$. & A & $\begin{array}{c}18.70 \\
(10.7-31.7)\end{array}$ & $\begin{array}{c}6.40 \\
(4.9-10.5)\end{array}$ & $\begin{array}{c}10.00 \\
(8.0-14.5)\end{array}$ & $\begin{array}{c}12.20 \\
(8.2-18.9)\end{array}$ \\
\hline Dysidea sp. & $\mathrm{E}$ & $\begin{array}{c}125.5 \\
(91.5-172.1)\end{array}$ & $\begin{array}{c}56.6 \\
(47.2-67.96)\end{array}$ & $\begin{array}{c}105 \\
(76.7-154.4)\end{array}$ & $\begin{array}{c}132.4 \\
(93.4-153.6)\end{array}$ \\
\hline Echinodictyum dendroides & $\mathrm{E}$ & $>500$ & $>500$ & $>500$ & $>500$ \\
\hline Haliclona implexiformis & $\mathrm{E}$ & $\begin{array}{c}434.3 \\
(291.9-548.6)\end{array}$ & $>500$ & $>500$ & $>500$ \\
\hline Haliclona melana & $\mathrm{E}$ & $>500$ & $>500$ & $>500$ & $>500$ \\
\hline Haliclona sp. & $\mathrm{E}$ & $>500$ & $>500$ & $>500$ & $>500$ \\
\hline Scopalina ruetzleri & $\mathrm{E}$ & $\begin{array}{c}369.5 \\
(317.0-430.6)\end{array}$ & $\begin{array}{c}253.1 \\
(215.3-297.5)\end{array}$ & $\begin{array}{c}376.3 \\
(258.8-547.2)\end{array}$ & $\begin{array}{c}381.5 \\
(288.4-507.6)\end{array}$ \\
\hline Tedania ignis & $\mathrm{E}$ & $\begin{array}{c}30.2 \\
(11.26-50.85)\end{array}$ & $\begin{array}{c}16.5 \\
(13.19-20.72) \\
\end{array}$ & $\begin{array}{c}17.8 \\
(14.02-22.64)\end{array}$ & $\begin{array}{c}37.9 \\
(31.77-45.42) \\
\end{array}$ \\
\hline \multirow{2}{*}{ Species } & \multirow{2}{*}{ Extracts } & \multicolumn{4}{|c|}{ Cell lines } \\
\hline & & A549 & HCT-8 & PC-3 & VERO \\
\hline Corals & \multicolumn{5}{|c|}{ IC $_{50}(95 \%$ confidence interval $)$} \\
\hline Agaricia humilis & $\mathrm{E}$ & & & & \\
\hline Carijoa riisei & $\mathrm{E}$ & $\begin{array}{c}181.9 \\
(108.8-304.0)\end{array}$ & $\begin{array}{c}102.6 \\
(89.5-117.7)\end{array}$ & $\begin{array}{c}199.7 \\
(96.32-314.1)\end{array}$ & $\begin{array}{c}172.66 \\
(106.6-321.1)\end{array}$ \\
\hline Favia gravida & $\mathrm{E}$ & $\begin{array}{c}277.9 \\
(196.1-393.8)\end{array}$ & $\begin{array}{c}295.7 \\
(238.0-367.2)\end{array}$ & $\begin{array}{c}454.1 \\
(285.2-722.9)\end{array}$ & $\begin{array}{c}243.1 \\
(180.3-312.8)\end{array}$ \\
\hline Millepora alcicornis & $\mathrm{E}$ & $>500$ & $>500$ & $>500$ & $>500$ \\
\hline Millepora brasiliensis & $\mathrm{E}$ & $>500$ & $>500$ & $>500$ & $>500$ \\
\hline Montastrea cavernosa & $\mathrm{E}$ & $>500$ & $>500$ & $>500$ & $>500$ \\
\hline Muriceopsis sulphurea & $\mathrm{E}$ & $>500$ & $>500$ & $>500$ & $>500$ \\
\hline Mussismilia harttii & $\mathrm{E}$ & $\begin{array}{c}189.7 \\
(126.8-283.6)\end{array}$ & $\begin{array}{c}158.1 \\
(130.0-192.1)\end{array}$ & $\begin{array}{c}254.7 \\
(109.5-451.2)\end{array}$ & $\begin{array}{c}159.6 \\
(132.6 \text { a } 192.1)\end{array}$ \\
\hline Mussismilia hispida & $\mathrm{E}$ & $>500$ & $>500$ & $>500$ & $>500$ \\
\hline Palythoa caribaeorum & $\mathrm{E}$ & $>500$ & $>500$ & $>500$ & $>500$ \\
\hline Plexaurella grandiflora & $\mathrm{E}$ & $\begin{array}{c}129.6 \\
(72.06-233.2)\end{array}$ & $\begin{array}{c}84.45 \\
(74.87-95.26)\end{array}$ & $\begin{array}{c}164.9 \\
(77.92-349.1)\end{array}$ & $\begin{array}{c}107.07 \\
(97.02-251.5)\end{array}$ \\
\hline Porites asteroides & $\mathrm{E}$ & $>500$ & $>500$ & $>500$ & $>500$ \\
\hline Scolymia wellsi & $\mathrm{E}$ & $>500$ & $>500$ & $>500$ & $>500$ \\
\hline $\begin{array}{l}\text { Siderastrea stellata } \\
\text { Paclitaxel }\end{array}$ & $\mathrm{E}$ & $\begin{array}{c}444.8 \\
(229.4-562.5) \\
0.14 \\
(0.06-0.18)\end{array}$ & $\begin{array}{c}382.9 \\
(309.3-473.9) \\
0.18 \\
(0.12-0.26)\end{array}$ & $\begin{array}{c}403.7 \\
(301.3-556.5) \\
0.57 \\
(0.42-0.70)\end{array}$ & $\begin{array}{c}476.2 \\
(299.4-601.6) \\
>500\end{array}$ \\
\hline
\end{tabular}

A: acetone extract; E: ethanolic extract; D: dichloromethane extract.

\subsection{Antiprotozoal activity}

The antiprotozoal screening against L. amazonensis and $T$. cruzi of the same marine invertebrate species tested above showed that the ethanolic extract of Amphimedon compressa and the acetone and ethanolic extracts of Dysidea sp. presented the most promising results (Table 3).

In view of the promising activity of the ethanolic extract of Amphimedon compressa and the acetone and ethanolic extracts of Dysidea sp., they were assayed against
L. amazonensis and T. cruzi intracellular amastigotes to determine their $\mathrm{IC}_{50}$ values and selective indices (Table 4). Despite of the activity observed and showed in Table 3 , the results on the human macrophage cell line THP-1 pointed to a low specificity.

\subsection{Anti-herpes activity}

The results of the anti-herpes screening indicated that the ethanolic extracts of Chondrosia collectrix and Haliclona sp. $(200 \mu \mathrm{g} / \mathrm{mL})$ completely inhibited 
Table 3. Percentages of growth inhibition of Leishmania amazonensis and Trypanosoma cruzi caused by marine invertebrate extracts (sponges and corals) at $50 \mu \mathrm{g} / \mathrm{mL}$.

\begin{tabular}{|c|c|c|c|}
\hline $\begin{array}{c}\text { Species } \\
\text { Sponoes }\end{array}$ & \multirow[t]{2}{*}{ Extracts } & \multirow{2}{*}{$\begin{array}{l}\% \text { growth inhibition } \pm \mathrm{SD} \\
\text { Leishmania amazonensis }\end{array}$} & \multirow{2}{*}{$\begin{array}{c}\% \text { growth inhibition } \pm \mathrm{SD} \\
\text { Trypanosoma cruzi }\end{array}$} \\
\hline Sponges & & & \\
\hline Amphimedon compressa & $\mathrm{E}$ & $61.73 \pm 3.62$ & $98.20 \pm 0.10$ \\
\hline Chondrilla caribensis & A & $32.68 \pm 2.78$ & $2.32 \pm 1.25$ \\
\hline Chondrilla caribensis & $\mathrm{E}$ & $17.91 \pm 3.40$ & $4.06 \pm 0.54$ \\
\hline Chondrosia collectrix & $\mathrm{E}$ & $31.56 \pm 0.91$ & $2.70 \pm 0.24$ \\
\hline Chondrosia collectrix & $\mathrm{D}$ & $27.26 \pm 2.57$ & $0.57 \pm 0.05$ \\
\hline Cinachyrella sp. & $\mathrm{E}$ & ND & $1.25 \pm 0.47$ \\
\hline Cladocroce caelum & $\mathrm{E}$ & ND & $12.00 \pm 0.58$ \\
\hline Desmapsamma anchorata & $\mathrm{E}$ & $35.42 \pm 1.27$ & $2.57 \pm 0.20$ \\
\hline Dysidea etheria & $\mathrm{E}$ & ND & $14.69 \pm 1.07$ \\
\hline Dysidea etheria & A & $3.89 \pm 0.52$ & $15.20 \pm 1.40$ \\
\hline Dysidea sp. & A & $80.30 \pm 2.15$ & $96.48 \pm 0.65$ \\
\hline Dysidea sp. & $\mathrm{E}$ & $64.44 \pm 0.74$ & $74.69 \pm 2.78$ \\
\hline Echinodictyum dendroides & $\mathrm{E}$ & $29.43 \pm 3.80$ & $3.73 \pm 0.30$ \\
\hline Haliclona implexiformis & $\mathrm{E}$ & ND & $1.58 \pm 0.07$ \\
\hline Haliclona melana & $\mathrm{E}$ & $4.59 \pm 0.95$ & $8.81 \pm 0.58$ \\
\hline Haliclona sp. & $\mathrm{E}$ & $24.47 \pm 6.17$ & $7.47 \pm 0.27$ \\
\hline Scopalina ruetzleri & $\mathrm{E}$ & ND & $9.29 \pm 0.23$ \\
\hline Tedania ignis & $\mathrm{E}$ & $4.17 \pm 1.10$ & $16.86 \pm 2.04$ \\
\hline Species & \multirow{2}{*}{ Extracts } & $\%$ growth inhibition \pm SD & $\%$ growth inhibition \pm SD \\
\hline Corals & & Leishmania amazonensis & Trypanosoma cruzi \\
\hline Agaricia humilis & $\mathrm{E}$ & $6.47 \pm 0.24$ & $9.18 \pm 1.60$ \\
\hline Carijoa riisei & $\mathrm{E}$ & $10.04 \pm 1.82$ & $4.10 \pm 0.66$ \\
\hline Favia gravida & $\mathrm{E}$ & $8.75 \pm 3.43$ & ND \\
\hline Millepora alcicornis & $\mathrm{E}$ & $16.23 \pm 3.43$ & ND \\
\hline Millepora brasiliensis & $\mathrm{E}$ & $23.26 \pm 1.82$ & $6.52 \pm 2.59$ \\
\hline Montastrea cavernosa & $\mathrm{E}$ & ND & ND \\
\hline Muriceopsis sulphurea & $\mathrm{E}$ & $17.30 \pm 0.93$ & $9.66 \pm 1.53$ \\
\hline Mussismilia harttii & $\mathrm{E}$ & $3.87 \pm 0.82$ & ND \\
\hline Mussismilia hispida & $\mathrm{E}$ & $29.08 \pm 3.35$ & $2.00 \pm 0.60$ \\
\hline Palythoa caribaeorum & $\mathrm{E}$ & $14.25 \pm 3.10$ & $2.93 \pm 1.32$ \\
\hline Plexaurella grandiflora & $\mathrm{E}$ & $21.57 \pm 2.63$ & $3.93 \pm 1.21$ \\
\hline Porites asteroides & $\mathrm{E}$ & $15.15 \pm 2.50$ & $4.41 \pm 0.65$ \\
\hline Scolymia wellsi & $\mathrm{E}$ & $26.34 \pm 3.29$ & $2.51 \pm 0.07$ \\
\hline Siderastrea stellata & $\mathrm{E}$ & $21.09 \pm 0.81$ & ND \\
\hline Amphotericin B $(1.84 \mu \mathrm{g} / \mathrm{mL})$ & - & $96.59 \pm 1.79$ & ND \\
\hline Benznidazole $(5.2 \mu \mathrm{g} / \mathrm{mL})$ & - & ND & $90.93 \pm 0.57$ \\
\hline
\end{tabular}

ND: not detected; A: acetone extract; E: ethanolic extract; D: dichloromethane extract.

Table 4. Leishmanicidal and trypanocidal activities of the extracts of two marine sponges on Leishmania amazonensis and Trypanosoma cruzi amastigotes in human macrophage THP-1 cell line.

\begin{tabular}{|c|c|c|c|c|c|c|}
\hline \multirow{2}{*}{ Species } & \multirow{2}{*}{ Extracts } & \multirow{2}{*}{$\frac{\text { THP-1 }}{\mathrm{CC}_{50} \pm \mathrm{SD}}$} & \multicolumn{2}{|c|}{ Leishmania amazonensis } & \multicolumn{2}{|c|}{ Trypanosoma cruzi } \\
\hline & & & $\mathrm{IC}_{50} \pm \mathrm{SD}$ & SI & $\mathrm{IC}_{50} \pm \mathrm{SD}$ & SI \\
\hline Amphimedon compressa & $\mathrm{E}$ & $13.96 \pm 1.70$ & $18.79 \pm 3.52$ & 0.74 & $26.94 \pm 3.87$ & 0.74 \\
\hline Dysidea $\mathrm{sp}$. & A & $<15.60$ & $16.37 \pm 2.43$ & $<0.95$ & $15.00 \pm 0.79$ & $<0.95$ \\
\hline Dysidea $\mathrm{sp}$. & E & $27.02 \pm 1.97$ & $34.80 \pm 1.29$ & 0.77 & $47.48 \pm 1.35$ & 0.77 \\
\hline Amphotericin B & & $24.95 \pm 0.18$ & $0.12 \pm 0.07$ & 207 & & \\
\hline Benznidazole & & $130.12 \pm 1.34$ & & & $2.6 \pm 0.22$ & 50 \\
\hline
\end{tabular}

A: acetone extract; E: ethanolic extract; $\mathrm{CC}_{50}$ and $\mathrm{IC}_{50}(\mu \mathrm{g} / \mathrm{mL})$; SI: selective index $=\left(\mathrm{CC}_{50} / \mathrm{IC}_{50}\right)$. 
HSV-1 (KOS strain) replication. The ethanolic extract of Amphimedon compressa and the acetone extract of Dysidea sp. were assayed only at very low concentrations (3.12 and $1.56 \mu \mathrm{g} / \mathrm{mL}$, respectively) due to their high cytotoxicity to VERO cells that are permissive to herpes viruses infection, but even at these low concentrations they showed to be active inhibiting viral replication by almost 50\% (Table 5).

In view of these promising results, the ethanolic extracts of the sponges Amphimedon compressa, Haliclona sp. and Chondrosia collectrix, as well as the acetone extract of Dysidea sp were further assayed to determine their $\mathrm{IC}_{50}$ and SI values. The results showed that the ethanolic extract of Haliclona sp. demonstrated the highest activity with a $\mathrm{SI}>50$ (Table 6)

Additionally, the ethanolic extract of Haliclona sp. was evaluated against other herpesvirus and strains [HSV-1 (29R strain) and HSV-2 (333 strain)]. The results demonstrated that this extract was also able to inhibit HSV-2 replication as well as the other tested strain of HSV-1, 29R, with high selective indices (Table 7). This is an important finding since 29R strain is resistant to acyclovir, the drug of choice to clinically treat herpes infections. In this Table 7, the results obtained with HSV-1 (KOS strain) (originally in Table 6) was inserted to compare the sponge activity against all tested viruses.

Table 5. Percentages of HSV-1 (KOS strain) inhibition after $48 \mathrm{~h}$ of treatment with marine invertebrate extracts (sponges and corals) by viral plaque number reduction assay.

\begin{tabular}{|c|c|c|c|}
\hline $\begin{array}{c}\text { Species } \\
\text { Sponges } \\
\end{array}$ & Extracts & $\begin{array}{c}\text { Tested concentration } \\
(\mu \mathrm{g} / \mathrm{mL})\end{array}$ & $\% \mathrm{HSV}-1$ inhibition \pm SD \\
\hline Amphimedon compressa & $\mathrm{E}$ & 3.12 & $49.25 \pm 5.76$ \\
\hline Chondrilla caribensis & A & 200 & 0 \\
\hline Chondrilla caribensis & $\mathrm{E}$ & 200 & 0 \\
\hline Chondrosia collectrix & $\mathrm{E}$ & 100 & $98.66 \pm 0.68$ \\
\hline Chondrosia collectrix & $\mathrm{D}$ & 200 & 0 \\
\hline Cinachyrella sp. & $\mathrm{E}$ & 200 & 0 \\
\hline Cladocroce caelum & $\mathrm{E}$ & 100 & 0 \\
\hline Desmapsamma anchorata & $\mathrm{E}$ & 200 & 0 \\
\hline Dysidea etheria & $\mathrm{E}$ & 100 & $33.97 \pm 9.47$ \\
\hline Dysidea etheria & A & 200 & 0 \\
\hline Dysidea sp. & A & 1.56 & $42.96 \pm 8.38$ \\
\hline Dysidea sp. & $\mathrm{E}$ & 50 & $13.75 \pm 6.26$ \\
\hline Echinodictyum dendroides & $\mathrm{E}$ & 200 & $3.40 \pm 1.04$ \\
\hline Haliclona implexiformis & $\mathrm{E}$ & 200 & $7.20 \pm 2.21$ \\
\hline Haliclona melana & $\mathrm{E}$ & 100 & $6.47 \pm 4.02$ \\
\hline Haliclona sp. & $\mathrm{E}$ & 50 & $100.00 \pm 0.00$ \\
\hline Scopalina ruetzleri & $\mathrm{E}$ & 100 & $14.19 \pm 5.34$ \\
\hline Tedania ignis & $\mathrm{E}$ & 50 & $40.88 \pm 3.88$ \\
\hline $\begin{array}{c}\text { Species } \\
\text { Corals } \\
\end{array}$ & Extracts & $\begin{array}{c}\text { Tested concentration } \\
(\mu \mathrm{g} / \mathrm{mL})\end{array}$ & $\% \mathrm{HSV}-1$ inhibition \pm SD \\
\hline Agaricia humilis & $\mathrm{E}$ & 100 & $16.95 \pm 7.11$ \\
\hline Carijoa riisei & $\mathrm{E}$ & 100 & $14.45 \pm 5.94$ \\
\hline Favia gravida & $\mathrm{E}$ & 100 & $27.72 \pm 8.91$ \\
\hline Millepora alcicornis & $\mathrm{E}$ & 100 & $5.69 \pm 3.16$ \\
\hline Millepora brasiliensis & $\mathrm{E}$ & 100 & $13.13 \pm .5 .53$ \\
\hline Montastrea cavernosa & $\mathrm{E}$ & 100 & $6.49 \pm 4.62$ \\
\hline Muriceopsis sulphurea & $\mathrm{E}$ & 100 & 0 \\
\hline Mussismilia harttii & $\mathrm{E}$ & 50 & $16.74 \pm 9.75$ \\
\hline Mussismilia hispida & $\mathrm{E}$ & 100 & 0 \\
\hline Palythoa caribaeorum & $\mathrm{E}$ & 100 & 0 \\
\hline Plexaurella grandiflora & $\mathrm{E}$ & 50 & $39.63 \pm 15.64$ \\
\hline Porites asteroides & $\mathrm{E}$ & 100 & $14.88 \pm 4.52$ \\
\hline Scolymia wellsi & $\mathrm{E}$ & 100 & 0 \\
\hline Siderastrea stellata & $\mathrm{E}$ & 100 & $20.52 \pm 8.29$ \\
\hline
\end{tabular}

A: acetone extract; E: ethanolic extract; D: dichloromethane extract. 
Table 6. Anti-herpes (HSV-1, KOS strain) activity after $48 \mathrm{~h}$ of treatment with four marine sponge extracts by viral plaque number reduction assay.

\begin{tabular}{|c|c|c|c|c|}
\hline \multirow{2}{*}{ Species } & \multirow{2}{*}{ Extract } & \multicolumn{2}{|c|}{$\mathrm{CC}_{50} \mathrm{IC}_{50} \pm \mathrm{SD}$} & \multirow{2}{*}{ SI } \\
\hline & & VERO cells & HSV-1 & \\
\hline Amphimedon compressa & $\mathrm{E}$ & $\begin{array}{c}9.9 \\
(7.2 \text { a } 13.6)\end{array}$ & $2.40 \pm 0.68$ & 4.1 \\
\hline Chondrosia collectrix & $\mathrm{E}$ & $\begin{array}{c}444.9 \\
(359.3 \text { a } 550.8)\end{array}$ & $60.00 \pm 5.35$ & 7.4 \\
\hline Dysidea $\mathrm{sp}$. & A & $\begin{array}{c}12.2 \\
(8.2 \mathrm{a} 18.9)\end{array}$ & $2.03 \pm 0.71$ & 6.0 \\
\hline Haliclona sp. & $\mathrm{E}$ & $>500$ & $10.03 \pm 2.14$ & $>50$ \\
\hline
\end{tabular}

Table 7. Anti-herpes activity [anti-HSV-1 (KOS and 29R strains) and anti-HSV-2 (333 strain)] after $48 \mathrm{~h}$ of treatment with the ethanolic extract of Haliclona sp. by viral plaque number reduction assay.

\begin{tabular}{|c|c|c|c|c|c|c|c|}
\hline \multirow[b]{2}{*}{ Sponge } & \multicolumn{4}{|c|}{$\mathrm{CC}_{50} \mathrm{IC}_{50} \pm \mathrm{SD}$} & \multicolumn{3}{|c|}{ Selective indices } \\
\hline & VERO cells & $\begin{array}{c}\text { HSV-1 } \\
\text { (KOS strain) }\end{array}$ & $\begin{array}{c}\text { HSV-1 } \\
\text { (29R strain) }\end{array}$ & $\begin{array}{c}\text { HSV-2 } \\
\text { (333 strain) }\end{array}$ & $\begin{array}{c}\text { HSV-1 } \\
\text { (KOS strain) }\end{array}$ & $\begin{array}{c}\text { HSV-1 } \\
\text { (29R strain) }\end{array}$ & $\begin{array}{c}\text { HSV-2 } \\
\text { (333 strain) }\end{array}$ \\
\hline Haliclona sp. & $>500$ & $10.03 \pm 2.14$ & $6.28 \pm 2.47$ & $4.59 \pm 1.09$ & $>50$ & $>79$ & $>108$ \\
\hline Acyclovir & $>500$ & $1.23 \pm 0.51$ & - & $3.48 \pm 0.76$ & $>406$ & - & $>143$ \\
\hline
\end{tabular}

$\mathrm{CC}_{50}$ and $\mathrm{IC}_{50}(\mu \mathrm{g} / \mathrm{mL})$; SI: selective index $=\mathrm{CC}_{50} / \mathrm{IC}_{50}$.

\subsection{Antibacterial activity}

The results of the antibacterial screening against Enterococcus faecalis, Pseudomonas aeruginosa and Escherichia coli indicated that only the ethanolic extract of Amphimedon compressa exhibited a weak antibacterial activity with inhibition halos ranging from 7.0 to $8.5 \mathrm{~mm}$.

\section{Discussion}

The evaluation of antiproliferative effects of 32 marine invertebrate extracts revealed that the ethanolic extracts of Amphimedon compressa and Tedania ignis, and the acetone extract of Dysidea sp showed results that can be considered relevant.

The species Amphimedon compressa (formerly Haliclona rubens) belongs to the order Haplosclerida. Marine sponges belonging to this order contributed with about $14 \%$ of the bioactive compounds isolated from marine sponges (Mehbub et al., 2014), and are a rich source of alkaloids with pronounced biological activities (Andersen et al., 1996; Almeida et al., 1997). Considering the previous published results with sponges of this genus, Berlinck and colleagues performed a screening with methanol-soluble crude extracts of sponges collected in southeastern Brazilian coast, and observed that Amphimedon viridis (formerly Haliclona viridis) displayed potent cytotoxic and hemolytic activities (Berlinck et al., 2004). The same authors reported latter the isolation of a new purine, 1,3-dimethylisoguanine (Chehade et al., 1997) from this species. Another research group reported the isolation of the same compound from the same sponge at the same time. The authors tested it against 26 human cancer cell lines and observed that it displayed the highest cytotoxic activity against an ovarian cancer cell line (Mitchell et al., 1997).
Another paper reported the cytotoxic screening of hydro-methanolic extracts of eight sponges collected in the northwest Brazilian coast (Ceará state), and it was found that the extract of Amphimedon sp. showed antiproliferative effects on three tumor cell lines [CEM and HL-60 (human leukemia cells) and HCT-8 (human ileocecal adenocarcinoma cells), with no effects on the murine melanoma (B-16) tested (Jimenez et al., 2004).

Concerning the antiproliferative effects of Dysidea sp. reported here, there is already another work describing the antimicrobial (bacteria and yeasts), antimycobacterial, antileishmania, and cytotoxic screenings of several samples of Dysidea sp. collected along the Brazilian southeastern and northeastern coastline, which showed that the crude extracts of four out of the eleven samples tested were strongly active against MCF-7 breast and HCT-8 colon cancer cells (Seleghim et al., 2007).

Regarding the leishmanicidal and tripanocidal activities, the extracts of Amphimedon compressa and the acetone and ethanolic extracts of Dysidea sp. showed promising results. However, both extracts showed very low selectivity indices using THP-1 cell line indicating that they are no specific. There are few reports of antiprotozoal activity of marine sponges and corals in the literature. As example two reports can be cited: firstly, De Paula and co-workers evaluated the in vitro activity of five species of Brazilian and Spanish marine sponges against $T$. cruzi, and showed that the acetone extract of Dysidea avara collected in Spanish coast presented high activity against trypomastigote forms (Paula et al., 2015). Secondly, Andrade et al. (2015) investigated the activity of organic and aqueous extracts obtained from the sponge Amphimedon viridis collected in southern Brazilian coast against T. cruzi and demonstrated 
that both extracts displayed concentration-dependent lytic effects on bloodstream trypomastigotes. The aqueous extract was $\sim 19$-fold more active than benznidazole used as positive control. Trypomastigotes treated with the aqueous extract and labelled with tetramethylrhodamine led to mitochondrial membrane potential dissipation on almost $80 \%$ of the parasites, whereas labelling with 7-aminoactinomycin D induced apoptosis-like death in almost $50 \%$ of the parasites. These data suggest a relevant trypanocidal activity of $A$. viridis, which is partially associated with the ability to induce apoptosis-like death (Andrade et al., 2015).

Regarding the anti-herpes activity, the ethanolic extract of Haliclona sp. showed the most promising results. When comparing the inhibition of HSV replication, HSV- 2 was observed to be more sensitive to Haliclona sp. followed by HSV-1-29-R, a resistant ACV strain. Additionally, the SI value showed by Haliclona for HSV-2 was > 108, comparable to that found for ACV ( $>143)$, used as positive control. Taken together, these results can be considered an advantage among other samples, since the emergence of resistant strains to ACV has been a challenge to treat herpes infections. Most of the antiherpetic drugs available share the same mechanism resulting in cross-resistance and attesting the necessity to find new treatment alternatives (Silva-Mares et al., 2016).

The order Haplosclerida, which includes the sponge genera Haliclona, Xestospongia and Amphimedon, is a rich source of $\beta$-carboline alkaloids called manzamines. They were first isolated by Higa and co-workers in 1986 from the Okinawan sponge genus Haliclona (Sakai et al., 1986). Until 2016, over 80 manzamine-related alkaloids have been reported from more than 16 marine sponge species belonging to five families (Hu et al., 2003; Peng et al., 2003). Manzamine A, 8-hydroxymanzamine A, and 8-methoxymanzamine A showed moderate activity against HSV-2 replication (Radwan et al., 2012; Palem et al., 2011). Palem et al. (2011) concluded that manzamine A, isolated from the Indo-Pacific sponge Acanthostrongylophora sp., displayed potent activity against HSV-1 replication, via targeting the viral gene infectious cellular protein ICP0. Furthermore, aiming to discover new natural product groups that could inhibit virus replication and control HSV-1 infections, they screened ten compounds of different chemical classes isolated from diverse marine sponges. They observed that the anti-HSV-1 activity of 8-hydroxymanzamine A was lower, when compared to that of manzamine A, suggesting that C-8 hydroxy substitution was involved in the anti-herpes activity. Moreover, when manzamine A was chemically transformed to its salt forms, the anti-HSV-1 activity was improved suggesting that augmentation of the overall water solubility can significantly enhance the activity (Jayavardhana et al., 2017). In view of these data and also considering the previous published work of our group (Bianco et al., 2013) that showed the anti-herpes activity of the buthanolic extract of Haliclona sp. collected in Aranhas Island, Santa Catarina State, South Brazil, species of this genus should receive special attention for future works aiming the isolation and structural elucidation of their bioactive metabolites.

The antibacterial screening showed that the only positive result was observed for the ethanolic extract of Amphimedon compressa. Interestingly, in the literature there are some previous works reporting, for example, the antibacterial activity of a hydro-methanolic extract of Amphimedon sp. against Staphylococus aureus as well as Pseudomonas aeruginosa strains (Jimenez et al., 2004). In another study with crude extracts of sponges collected in Rio de Janeiro state, Brazil, the crude extract of Amphimedon sp. also showed a weak antibacterial activity against oxacillin-resistant $S$. aureus) (Seleghim et al., 2007).

\section{Conclusion}

In this work, 32 different extracts from Brazilian marine invertebrates were screened for their potential antiproliferative, antibacterial, antiprotozoal and anti-herpes activities. The results showed that the sponges Amphimedon compressa, Chondrosia collectrix, Tedania ignis, Dysidea sp., and Haliclona sp. were the species presenting the most important bioactivities, and deserve further investigations. Special attention should be given to the sponge Haliclona sp. regarding its antiherpes activity against all tested strains with emphasis to HSV-1 (29R strain, which is resistant to acyclovir, $\mathrm{SI}=79)$ and to HSV-2 $(\mathrm{SI}=108)$.

\section{Acknowledgments}

The authors thank Conselho Nacional de Desenvolvimento Científico e Tecnológico (CNPq), Coordenação de Aperfeiçoamento de Pessoal de Nível Superior (CAPES, MEC, PNPD) for fellowships; CNPq -MCTI (grant number 408934/2013-1)] and Fundação de Amparo à Pesquisa e Inovação do Estado de Santa Catarina (FAPESC (grant number 14170/2010) for their financial support.

\section{References}

ALMEIDA, A.M.P., BERLINCK, R.G.S. and HAJDU, E., 1997. Alcaloides alquilpiridínicos de esponjas marinhas. Quimica Nova, vol. 20, no. 2, pp. 170-185. http://dx.doi.org/10.1590/ S0100-40421997000200009.

ALMEIDA, M.T.R., MORITZ, M.I.G., CAPEL, K.C.C., PÉREZ, C.D. and SCHENKEL, E.P., 2014. Chemical and biological aspects of octocorals from the Brazilian coast. Revista Brasileira de Farmacognosia, vol. 24, no. 4, pp. 446-467. http://dx.doi. org/10.1016/j.bjp.2014.05.002.

ANDERSEN, R.J., VAN SOEST, R.W.M. and KONG, F., 1996. 3-Alkylpiperidine alkaloids isolated from marine sponges in the order Haplosclerida. In: S.W. PELLETIER, ed. The Alkaloids: chemical and biological perspectives. New York: Pergamon Press.

ANDRADE, A.A., GAMA, A.N.S., TEIXEIRA, G.S., ATELLA, G.C., CASTRO, S.L., COUTINHO, C.C. and SOUZA, E.M., 2015. Activity of marine sponge-derived extracts against Trypanossoma cruzi associated with apoptosis-like death. International Journal of Reserach Studies in Bioscience, vol. 3, pp. 92-101. 
BERLINCK, R.G., HAJDU, E., ROCHA, R.M., OLIVEIRA, J.H., HERNÁNDEZ, I.L., SELEGHIM, M.H., GRANATO, A.C., ALMEIDA, E.V., NUÑEZ, C.V., MURICY, G., PEIXINHO, S., PESSOA, C., MORAES, M.O., CAVALCANTI, B.C., NASCIMENTO, G.G., THIEMANN, O., SILVA, M., SOUZA, A.O., SILVA, C.L. and MINARINI, P.R., 2004. Challenges and rewards of research in marine natural products chemistry in Brazil. Journal of Natural Products, vol. 67, no. 3, pp. 510-522. http:// dx.doi.org/10.1021/np0304316. PMid:15043447.

BIANCO, E.M., OLIVEIRA, S.Q., RIGOTTO, C., TONINI, M.L., GUIMARÃES, T.R., BITTENCOURT, F., GOUVÊA, L.P., ARESI, C., ALMEIDA, M.T.R., MORITZ, M.I.G., MARTINS, C.D.L., SCHERNER, F., CARRARO, J.L., HORTA, P.A., REGINATTO, F.H., STEINDEL, M., SIMÕES, C.M.O. and SCHENKEL, E.P., 2013. Anti-Infective potential of marine invertebrates and seaweeds from the Brazilian coast. Molecules, vol. 18, no. 5, pp. 5761-5778. http://dx.doi.org/10.3390/ molecules18055761. PMid:23681060.

BLUNT, J.W., COPP, B.R., HU, W.P., MUNRO, M.H.G., NORTHCOTE, P.T. and PRINSEP, M.R., 2008. Marine natural products. Natural Product Reports, vol. 25, no. 1, pp. 35-94. http:// dx.doi.org/10.1039/b701534h. PMid:18250897.

BLUNT, J.W., COPP, B.R., KEYZERS, R.A., MUNRO, M.H.G. and PRINSEP, M.R., 2017. Marine natural products. Natural Product Reports, vol. 34, no. 3, pp. 235-294. http://dx.doi. org/10.1039/C6NP00124F. PMid:28290569.

BLUNT, J.W., COPP, B.R., MUNRO, M.H.G., NORTHCOTE, P.T. and PRINSEP, M.R., 2010. Marine natural products. Natural Product Reports, vol. 27, no. 2, pp. 165-237. http://dx.doi. org/10.1039/b906091j. PMid:20111802.

BOFF, L., SILVA, I.T., ARGENTA, D.F., FARIAS, L.M., ALVARENGA, L.F., PÁDUA, R.M., BRAGA, F.C., LEITE, J.P., KRATZ, J.M. and SIMÕES, C.M., 2016. Strychnos pseudoquina A. St. Hil.: a Brazilian medicinal plant with promising in vitro anti-herpes activity. Journal of Applied Microbiology, vol. 121, no. 6, pp. 1519-1529. http://dx.doi.org/10.1111/jam.13279. PMid:27566664

BUCKNER, F.S., VERLINDE, C.L., LA FLAMME, A.C. and VAN VOORHIS, W.C., 1996. Efficient technique for screening drugs for activity against Trypanosoma cruzi using parasites expressing beta-galactosidase. Antimicrobial Agents and Chemotherapy, vol. 40, no. 11, pp. 2592-2597. http://dx.doi. org/10.1128/AAC.40.11.2592. PMid:8913471.

BURLESON, F.G., CHAMBERTS, T.M. and WIEDBRAUK, D.L., 1992. Virology: a laboratory manual. San Diego: Academic.

CHEHADE, C.C., DIAS, R.L., BERLINCK, R.G., FERREIRA, A.G., COSTA, L.V., RANGEL, M., MALPEZZI, E.L., FREITAS, J.C. and HAJDU, E., 1997. 1.3-Dimethylisoguanine A - a new purine from the marine sponge Amphimedon viridis. Journal of Natural Products, vol. 60, no. 7, pp. 729-731. http://dx.doi. org/10.1021/np970021f. PMid:9249981.

CLINICAL AND LABORATORY STANDARDS INSTITUTE - CLSI, 2012. Performance standards for antimicrobial disk susceptibility tests, approved standard. 7th ed. Wayne: CLSI, CLSI document, M02-A11.

DALY, M., BRUGLER, M.R., CARTWRIGHT, P., COLLINS, A.G., DAWSON, M.N., FAUTIN, D.G., FRANCE, S.C., MCFADDEN, C.S., OPRESKO, D.M. and RODRIGUEZ, E., 2007. The phylum Cnidaria: a review of phylogenetic patterns and diversity 300 years after Linnaeus. Zootaxa, vol. 1668, pp. 127-182.
FONTANA, A., CIAVATTA, M.L. and CIMINO, G., 1998. Cladocoran A and B: two novel $\gamma$-hydroxy butenolide sesterterpenes from the Mediterranean coral Cladocora cespitosa. The Journal of Organic Chemistry, vol. 63, no. 9, pp. 2845-2849. http://dx.doi. org/10.1021/jo971586j.

FROTA, M.J., SILVA, R.B., MOTHES, B., HENRIQUES, A.T. and MOREIRA, J.C., 2012. Current status on natural products with antitumor activity from Brazilian marine sponges. Current Pharmaceutical Biotechnology, vol. 13, no. 1, pp. 235-244. http:// dx.doi.org/10.2174/138920112798868674. PMid:21466432.

HU, J.F., HAMANN, M.T., HILL, R. and KELLY, M., 2003. The manzamine alkaloids. The Alkaloids. Chemistry and Biology, vol. 60, pp. 207-285. http://dx.doi.org/10.1016/S0099-9598(03)600040. PMid: 14593858 .

JAYAVARDHANA, R., PALEM, M. M., SHAO-CHUNG, V., HSIA, S. C., \& EL SAYED, K. A. (2017). Discovery and preliminary structure-activity relationship of the marine natural product manzamines as Herpes Simplex Virus type 1 inhibitors. Z Naturforsch, 72(1-2), 49-54. PMid:27447204. http://dx.doi. org/10.1515/znc-2016-0080

JHA, R.K. and XU, Z., 2004. Biomedical compounds from marine organisms. Marine Drugs, vol. 2, no. 3, pp. 123-146. http://dx.doi.org/10.3390/md203123.

JIMENEZ, P.C., TEIXEIRA, G.L.S., WILKE, D.V., NOGUERIA, N.A.P., HADJU, E., PESSOA, C., MORAES, M.O. and COSTALOTUFO, L.V., 2004. Cytotoxic and antimicrobial activities of hydro-methanolic extracts of sponges (Porifera) from Ceará state, Brazil. Arquivos da Ciência Marinha, vol. 37, pp. 85-91.

KONG, D.X., JIANG, Y.Y. and ZHANG, H.Y., 2010. Marine natural products as sources of novel scaffolds: achievement and concern. Drug Discovery Today, vol. 15, no. 21-22, pp. 884-886. http://dx.doi.org/10.1016/j.drudis.2010.09.002. PMid:20869461.

LEAL, M.C., MADEIRA, C., BRANDÃO, C.A., PUGA, J. and CALADO, R., 2012. Bioprospecting of marine invertebrates for new natural products - a chemical and Zoogeographical Perspective. Molecules, vol. 17, no. 8, pp. 9842-9854. http://dx.doi.org/10.3390/ molecules 17089842. PMid:22898739.

LIMA, T.C., SOUZA, R.J., SANTOS, A.D., MORAES, M.H., BIONDO, N.E., BARISON, A., STEINDEL, M. and BIAVATTI, M.W., 2016. Evaluation of leishmanicidal and trypanocidal activities of phenolic compounds from Calea uniflora Less. Natural Product Research, vol. 30, no. 5, pp. 551-557. http:// dx.doi.org/10.1080/14786419.2015.1030740. PMid:25880257.

MEHBUB, M.F., LEI, J., FRANCO, C. and ZHANG, W., 2014. Marine sponge derived natural products between 2001 and 2010: trends and opportunities for discovery of bioactives. Marine Drugs, vol. 12, no. 8, pp. 4539-4577. http://dx.doi.org/10.3390/ md12084539. PMid:25196730.

MEYER, M., DELBERGHE, F., LIRON, F., GUILLAUME, M., VALENTIN, A. and GUYOT, M., 2009. An antiplasmodial new (bis)indole alkaloid from the hard coral Tubastraea sp. Natural Product Research, vol. 23, no. 2, pp. 178-182. http://dx.doi. org/10.1080/14786410801925134. PMid:19173125.

MITCHELL, S.S., WHITEHILL, A.B., TRAPIDO-ROSENTHAL, H.G. and IRELAND, C.M., 1997. Isolation and characterization of 1.3-dimethyl isoguanine from the Bermudian sponge Amphimedon viridis. Journal of Natural Products, vol. 60, no. 7, pp. 727-728. http://dx.doi.org/10.1021/np970015j. PMid:9249980. 
MIYAOKA, H., YAMANISHI, M. and MITOME, H., 2006. PLA2 inhibitory activity of marine sesterpenoids cladocorans, their diastereomers and analogues. Chemical \& Pharmaceutical Bulletin, vol. 54, no. 2, pp. 268-270. http://dx.doi.org/10.1248/ cpb.54.268. PMid:16462082.

MONKS, N.R., LERNER, C., HENRIQUES, A.T., FARIAS, F.M., SCHAPOVAL, E.E.S., SUYENAGA, E.S., ROCHA, A.B., SCHWARTSMANN, G. and MOTHES, B., 2002. Anticancer, antichemotactic and antimicrobial activities of marine sponges collected off the coast of Santa Catarina, southern Brazil. Journal of Experimental Marine Biology and Ecology, vol. 281, no. 1-2, pp. 1-12. http://dx.doi.org/10.1016/S0022-0981(02)00380-5

MONTASER, R. and LUESCH, H., 2011. Marine natural products: a new wave of drugs? Future Medicinal Chemistry, vol. 3, no. 12, pp. 1475-1489. http://dx.doi.org/10.4155/fmc.11.118. PMid:21882941.

OLIVEIRA, S.Q., TRENTIN, V.H., KAPPEL, V.D., BARELLI, C., GOSMANN, G. and REGINATTO, F.H., 2005. Screening of antibacterial activity of south Brazilian Baccharis species. Pharmaceutical Biology, vol. 43, no. 5, pp. 434-438. http://dx.doi. org/10.1080/13880200590963754.

PALEM, J.R., BEDADALA, G.R., EL SAYED, K.A. and HSIA, S.C., 2011. Manzamine A as a novel inhibitor of Herpes Simplex Virus type-1 replication in cultured corneal cells. Planta Medica, vol. 77, no. 1, pp. 46-51. http://dx.doi.org/10.1055/s-0030-1250093. PMid:20645244.

PAULA, J.C., DESOTI, V.C., SAMPIRON, E.G., MARTINS, S.C., UEDA-NAKAMURA, T., RIBEIRO, S.M., BIANCO, E.M., SILVA, S.O., OLIVEIRA, G.G. and NAKAMURA, C.V., 2015. Trypanocidal activity of organic extracts from the Brazilian and Spanish marine sponges. Revista Brasileira de Farmacognosia, vol. 25, no. 6, pp. 651-656. http://dx.doi. org/10.1016/j.bjp.2015.08.011

PENG, J., HU, J.F., KAZI, A.B., LI, Z., AVERY, M., PERAUD, O., HILL, R.T., FRANZBLAU, S.G., ZHANG, F., SCHINAZI, R.F., WIRTZ, S.S., THARNISH, P., KELLY, M., WAHYUONO, S. and HAMANN, M.T., 2003. Manadomanzamines A and B: a novel alkaloid ring system with potent activity against mycobacteria and HIV-1. Journal of the American Chemical Society, vol. 125, no. 44, pp. 13382-13386. http://dx.doi.org/10.1021/ja030087z. PMid:14583033.

PERDICARIS, S., VLACHOGIANNI, T. and VALAVANIDIS, A., 2013. Bioactive natural substances from marine sponges: new developments and prospects for future pharmaceuticals. Natural Products Chemistry \& Research, vol. 1, no. 3, pp. 1-8. http:// dx.doi.org/10.4172/2329-6836.1000114.

RADWAN, M., HANORA, A., KHALIFA, S. and ABOU-ELELA, S., 2012. Manzamines: a potential for novel cures. Cell Cycle, vol. 11, no. 9, pp. 1765-1772. http://dx.doi.org/10.4161/ cc.20135. PMid:22510565.

RANGEL, M., SANCTIS, B., FREITAS, J.C.F., POLATTO, J.M., GRANATO, A.C., BERLINCK, R.G.S. and HAJDU, E., 2001. Cytotoxic and neurotoxic activities in extracts of marine sponges (Porifera) from southeastern Brazilian coast. Journal of Experimental Marine Biology and Ecology, vol. 262, no. 1, pp. 31-40. http://dx.doi.org/10.1016/S0022-0981(01)00276-3.

ROCHA, J., PEIXE, L., GOMES, N.C.M. and CALADO, R., 2011. Cnidarians as a source of new marine bioactive compounds An overview of the last decade and future steps for bioprospecting. Marine Drugs, vol. 9, no. 10, pp. 1860-1886. http://dx.doi. org/10.3390/md9101860. PMid:22073000.

SAGAR, S., KAUR, M. and MINNEMAN, K.P., 2010. Antiviral lead compounds from marine sponges. Marine Drugs, vol. 8, no. 10 , pp. 2619-2638. http://dx.doi.org/10.3390/md8102619. PMid:21116410.

SAKAI, R., HIGA, T., JEFFORD, C. and BERNARDINELLI, G., 1986. Manzamine A. A novel antitumor alkaloid from a sponge. Journal of the American Chemical Society, vol. 108, no. 20, pp. 6404-6405. http://dx.doi.org/10.1021/ja00280a055.

SCHWENDE, H., FITZKE, E., AMBS, P. and DIETER, P., 1996. Differences in the state of differentiation of THP-1 cells induced by phorbol ester and 1,25-dihydroxyvitamin D3. Journal of Leukocyte Biology, vol. 59, no. 4, pp. 555-561. http://dx.doi. org/10.1002/jlb.59.4.555. PMid:8613704.

SELEGHIM, M.H.R., LIRA, S.P., KOSSUGA, M.H., BATISTA, T., BERLINCK, R.G.S., HAJDU, E., MURICY, G., ROCHA, R.M., NASCIMENTO, G.G.F., SILVA, M., PIMENTA, E.F., THIEMANN, O.H., OLIVA, G., CAVALCANTI, B.C., PESSOA, C., MORAES, M.O., GALETTI, F.C.S., SILVA, C.L., SOUZA, A.O. and PEIXINHO, S., 2007. Antibiotic, cytotoxic and enzyme inhibitory activity of crude extracts from Brazilian marine invertebrates. Brazilian Journal of Pharmacognosy, vol. 17 , no. 3, pp. 287-318. http://dx.doi.org/10.1590/S0102$695 \times 2007000300002$

SILVA-MARES, D., TORRES-LÓPEZ, E. and RIVASGALINDO, V.M., 2016. Antiherpetic plants: a review of active extracts, isolated compounds, and bioassays. Natural Product Communications, vol. 11, no. 4, pp. 557-566. http://dx.doi. org/10.1177/1934578X1601100434. PMid:27396217.

ŠTRUKELJ, B., LENARCIC, B., GRUDEN, K., PUNGERCAR, J., ROGELJ, B., TURK, V., BOSCH, D. and JONGSMA, M.A., 2000. Equistatin, a protease inhibitor from the sea anemone Actinia equina is composed of three structural and functional domains. Biochemical and Biophysical Research Communications, vol. 269, no. 3, pp. 732-736. http://dx.doi.org/10.1006/bbrc.2000.2356. PMid:10720485.

VICHAI, V. and KIRTIKARA, K., 2006. Sulforhodamine B colorimetric assay for cytotoxicity screening. Nature Protocols, vol. 1, no. 3, pp. 1112-1116. http://dx.doi.org/10.1038/nprot.2006.179. PMid: 17406391.

VILLA, F.A. and GERWICK, L., 2010. Marine natural product drug discovery: leads for treatment of inflammation, cancer, infections and neurological disorders. Immunopharmacology and Immunotoxicology, vol. 32, no. 2, pp. 228-237. http://dx.doi. org/10.3109/08923970903296136. PMid:20441539. 